www.nature.com/pj

\title{
Inclusion of fullerene in polymer chains grafted on silica nanoparticles in an organic solvent
}

\author{
Kohji Yoshinaga ${ }^{1}$, Yin Yang ${ }^{2}$, Teruhisa Ohno ${ }^{2}$, Suguru Motokucho ${ }^{1}$ and Ken Kojio ${ }^{1}$ \\ Polymer Journal (2014) 46, 623-627; doi:10.1038/pj.2014.24; published online 14 May 2014
}

Keywords: fullerene; inclusion; polymer-grafted silica; nanoparticles

Fullerene has received much interest for applications in smart and functional materials owing to its characteristic properties, such as electron-accepting or -releasing capacity, high refractive index, high heat conductivity and absorption in the UV region. So far, a number of papers have reported fundamental and practical studies employing modified or unmodified fullerenes in applications such as solar cell devices, fillers and semiconductors. ${ }^{1-4}$ In most cases, a surface modification of fullerenes was performed to promote dispersion or to increase the solubility of the fullerenes in solution. ${ }^{5}$ However, surface modification by a covalent bond sometimes spoils the innate properties of fullerene. Furthermore, the addition of surfactants causes fullerene to leak from the final products and contaminate the environment. In this regard, in our previous study we showed that a polymer dispersant, poly(methyl methacrylate-co-2-naphthyl methacrylate) (poly(MMA-NMA)), effectively disperses fullerene in an organic solvent without spoiling the original properties of fullerene. ${ }^{6}$

Silica is widely used as a raw material in many applications, including paints, fillers of plastics, carriers of catalysts, supports in heterogeneous organic synthesis and stationary phase of chromatography, owing to its nontoxicity, stability and availability. A recent development in colloid chemistry also made it possible to control the size of the colloidal inorganic particles ranging from nanometer to micrometer size. ${ }^{7}$ Nanometer-sized colloidal silica is an especially attractive material owing to its spherical shape, colorlessness and high stability in an aqueous solution. An aqueous solution containing colloidal silica $<20 \mathrm{~nm}$ is usually transparent. Therefore, polymer composites consisting of fairly well-dispersed fullerene and silica nanoparticles can result in the fabrication of unique functional materials, that is, silica-reinforced and heat-conductive transparent composites. In this study, the inclusion of fullerene $\left(\mathrm{C}_{60}\right)$ into poly(MMA-NMA) chains grafted on silica particles $12 \mathrm{~nm}$ in diameter in tetrahydrofuran (THF) without formation of $\mathrm{C}_{60}$ clusters and fabrication of transparent hybrid films composed of $\mathrm{C}_{60}$ and poly(MMA-NMA)-grafted silica composite were investigated.
According to our previous study, ${ }^{6}$ the poly(MMA-NMA)s to MMA/ NMA mole ratio of $1 / 6$ to $1 / 15$, and around number average molecular weight $\left(M_{\mathrm{n}}\right)=10000$ was effective as a dispersant of $\mathrm{C}_{60}$ in methyl methacrylate (MMA); therefore, the grafting copolymers were employed at a mole ratio ranging from $1 / 7$ to $1 / 14$.

\section{EXPERIMENTAL PROCEDURE}

\section{Materials}

A colloidal silica aqueous sol, containing $30 \mathrm{wt} \% \mathrm{SiO}_{2} 9.1 \mathrm{~nm}$ in diameter and with a polydispersity index of 0.127 , was kindly provided by Nikki Catalysts \& Chemical Co. Ltd, Kanagawa, Japan. Colloidal silica suspended in ethanol was prepared by solvent exchange with azeotropic evaporation of water after the addition of ethanol to the original aqueous solution. Fullerene $\left(\mathrm{C}_{60}\right)$, Nanom purple ST, was purchased from Frontier Carbon Co. Ltd, Tokyo, Japan. MMA and other chemicals were obtained from Wako Chemicals Co. Ltd, Osaka, Japan. (3-Aminopropyl) trimethoxysilane was purchased from Kanto Chemicals Co. Ltd, Tokyo, Japan.

\section{Measurements}

The $M_{\mathrm{n}}$ and polydispersity $\left(M_{\mathrm{w}} / M_{\mathrm{n}}\right)$ of the synthesized polymers were determined by gel permeation chromatography on columns containing TSK gels $\mathrm{G}_{4000 \mathrm{H}_{6}}$ and $\mathrm{G} 000 \mathrm{H}_{6}$ (Tosoh Co. Ltd, Yamaguchi, Japan) at $35^{\circ} \mathrm{C}$, using THF as an eluent at a flow rate of $0.8 \mathrm{mlmin}^{-1}$ and calibrated with a polystyrene standard. ${ }^{1} \mathrm{H}$ nuclear magnetic resonance (NMR) spectra were recorded on a Bruker AVANCE $400(400 \mathrm{MHz})$, Karlsruhe, Germany. The amounts of grafted polymer were determined by a thermal gravimetric analysis on a TG-50, Shimadzu Co. Ltd, Kyoto, Japan, while elevating the temperature up to $800{ }^{\circ} \mathrm{C}$ at a heating rate of $10^{\circ} \mathrm{C} \mathrm{min}-1$. The particle size was determined by dynamic light scattering on an Otsuka Electronics DLS-7000 spectrophotometer equipped with a He-Ne laser $(10 \mathrm{~mW}, 633 \mathrm{~nm})$. The transmission spectra of the hybrid films were recorded on a multichannel spectrometer, Ohtsuka MCPD-3700, Osaka, Japan.

\section{Synthesis of NMA}

This compound was synthesized by the usual method that employs $2.8 \mathrm{~g} 2$ -

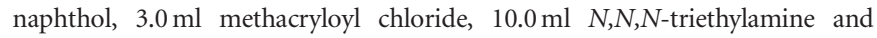
$18 \mathrm{ml}$ chloroform. Recrystallization from the methanol/water cosolvent (80/

${ }^{1}$ Division of Chemistry and Materials Science, Graduate School of Engineering, Nagasaki University, Nagasaki, Japan and ${ }^{2}$ Department of Applied Chemistry, Graduate School of Engineering, Kyushu Institute of Technology, Fukuoka, Japan

Correspondence: Professor K Yoshinaga, Division of Chemistry and Materials Science, Graduate School of Engineering, Nagasaki University, 14-1 Bunkyou-machi, Nagasaki 852-8521, Japan. 
$20 \mathrm{vol}$ ) and drying under reduced pressure yielded $3.3 \mathrm{~g}$ 2-naphthyl methacrylate (NMA). ${ }^{1} \mathrm{H}$ NMR $\left(\mathrm{CDCl}_{3}\right): 2.10\left(s, \mathrm{CH}_{3}\right), 5.79\left(d, \mathrm{CH}_{2}\right), 6.40\left(d, \mathrm{CH}_{2}\right)$, $7.26(d, 3-H$ (naphthyl)), $7.46(t, 8-H$ (naphthyl)), $7.49(t, 7-H$ (naphthyl)), 7.59 (s, 11-H (naphthyl)), 7.80 ( $d, 6-H$ (naphthyl)), 7.85 ( $d, 4-H$ (naphthyl)), $7.86(d, 9-H$ (naphthyl)) p.p.m.

\section{Synthesis of trimethoxysilyl-terminated poly(MMA-NMA)}

The polymer silanes were synthesized by following three methods, shown in Scheme 1.

Method $1 .{ }^{8}$ A mixture of $2.6 \mathrm{ml} \mathrm{MMA,} 0.40 \mathrm{~g}$ NMA and $10 \mathrm{ml}$ THF solution containing $14 \mathrm{mg}$ (3-mercaptopropyl)trimethoxysilane and $5 \mathrm{mg} \quad 2,2^{\prime}$ azobis(isobutylonitrile) was put into a 50-ml flask thoroughly purged with nitrogen. The mixture was stirred at $75^{\circ} \mathrm{C}$ for $8 \mathrm{~h}$. Precipitating with diethyl ether and drying under reduced pressure produced $1.5 \mathrm{~g}$ polymer silane 1 of MMA/NMA with a mole ratio $=14 / 1, M_{\mathrm{n}}=7400$ and $M_{\mathrm{w}} / M_{\mathrm{n}}=2.02 .{ }^{1} \mathrm{H}$ $\operatorname{NMR}\left(\mathrm{CDCl}_{3}\right): 0.84\left(s, \mathrm{CH}_{3}\right), 1.02\left(s, \mathrm{CH}_{3}\right), 1.34-1.67$ (broad, $\left.\mathrm{CH}_{2}\right), 1.71-2.22$ (broad, $\mathrm{CH}_{2}$ ), $3.59\left(\mathrm{~s}, \mathrm{CH}_{3}\right), 7.26$ ( $m, 3-\mathrm{H}$ (naphthyl)), 7.40-7.54 (broad, 8- $\mathrm{H}$, 9- $H$ (naphthyl)), 7.58 (broad, 10- $H$ (naphthyl)), 7.55-7.90 (broad, 4- $H, 6-H$, 9-H (naphthyl)) p.p.m.

Method 2.9 A mixture of $3.6 \mathrm{ml} \mathrm{MMA,} 0.70 \mathrm{~g}$ NMA and $10 \mathrm{ml}$ THF solution

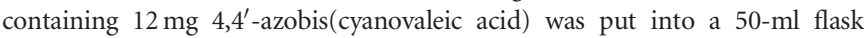
thoroughly purged with nitrogen. The mixture was stirred at $55^{\circ} \mathrm{C}$ for $12 \mathrm{~h}$.
Precipitating with methanol and drying under reduced pressure produced $2.4 \mathrm{~g}$ carboxyl-terminated polymer of MMA/NMA mole ratio $=7 / 1, M_{\mathrm{n}}=48000$ and $M_{\mathrm{w}} / M_{\mathrm{n}}=2.28 .{ }^{1} \mathrm{H}$ NMR $\left(\mathrm{CDCl}_{3}\right): 0.85\left(s, \mathrm{CH}_{3}\right), 1.02\left(s, \mathrm{CH}_{3}\right), 1.46-1.60$ $\left(m, \mathrm{CH}_{2}\right), 1.73-2.17\left(m, \mathrm{CH}_{2}\right), 3.60\left(s, \mathrm{CH}_{3}\right), 7.26$ ( $m, 3-\mathrm{H}$ (naphthyl)), 7.407.54 (broad, 8- $H, 9-H$ (naphthyl)), 7.58 (broad, 10-H (naphthyl)), 7.55-7.90 (broad, 4- $H, 6-H, 9-H$ (naphthyl)) p.p.m. A mixture of $2.4 \mathrm{~g}$ carboxylterminated poly(MMA-NMA), $15 \mathrm{mg} N, N^{\prime}$-dicyclohexylcarbodiimde and $30 \mathrm{ml}$ chloroform was put into a $50-\mathrm{ml}$ flask. The mixture was stirred in an ice bath for $30 \mathrm{~min}$. After the addition of $50 \mathrm{mg}$ (3aminopropyl)trimethoxysilane to the mixture, the resultant solution was stirred at room temperature for $5 \mathrm{~h}$. After removing $N, N^{\prime}$-dicyclohexylurea by filtration, precipitating with methanol and drying under reduced pressure produced $1.9 \mathrm{~g}$ polymer silane $2 .{ }^{1} \mathrm{H} \mathrm{NMR}\left(\mathrm{CDCl}_{3}\right): 0.84\left(s, \mathrm{CH}_{3}\right), 1.02(s$, $\left.\mathrm{CH}_{3}\right), 1.31-1.68$ (broad, $\left.\mathrm{CH}_{2}\right), 1.71-2.18$ (broad, $\left.\mathrm{CH}_{2}\right), 3.60\left(\mathrm{~s}, \mathrm{CH}_{3}\right), 7.26(\mathrm{~m}$, 3- $H$ (naphthyl)), 7.40-7.54 (broad, 8- $H, 9-H$ (naphthyl)), 7.58 (broad, $10-H$ (naphthyl)), 7.55-7.90 (broad, 4- H, 6- H, 9-H (naphthyl)) p.p.m.

Method $3 .{ }^{10}$ A mixture of $2.0 \mathrm{ml}$ MMA, $0.35 \mathrm{~g} \mathrm{NMA}, 1.5 \mathrm{ml}$ dry anisol containing $1.9 \mathrm{mg}$ 4-(1-bromoethyl)benzoic acid, $5.0 \mathrm{ml} \quad N, N, N^{\prime \prime}, N^{\prime \prime}, N^{\prime \prime}$ pentamethyldiethylenetriamine and $1.2 \mathrm{mg} \mathrm{CuBr}$ was put in a test tube. The test tube was purged with nitrogen during four freeze-and-thaw cycles. After sealing the tube, the solution was stirred at $85^{\circ} \mathrm{C}$ for $14 \mathrm{~h}$. Precipitating with methanol and drying under reduced pressure produced $1.1 \mathrm{~g}$ carboxylterminated poly(MMA-NMA) of MMA/NMA with a mole ratio $=8 / 1$,

\section{a Method 1}<smiles></smiles><smiles>COCCCS</smiles>

AlBN / dry THF<smiles>COC(=O)C(C)(C)CC(C)(C)C(=O)Oc1ccc2ccccc2c1</smiles>

b Method 2<smiles>C=C(C)C(=O)OC[CH-]C(=O)C(C)=O</smiles><smiles>CC(C)(C)Br</smiles><smiles>COC(=O)C(C)(C)CC(C)(C)C(C)(C)C(=O)Oc1ccc2ccccc2c1</smiles>

1) $\mathrm{DCC} / \mathrm{CH}_{3} \mathrm{Cl}$

2) $\mathrm{H}_{2} \mathrm{~N} \curvearrowright \mathrm{Si}(\mathrm{OMe})_{3}$<smiles>COC(=O)C(C)(C)CC(C)(C)C(C)(C)C(=O)Oc1ccc2ccccc2c1</smiles>

\section{Method 3}<smiles></smiles><smiles>COC(=O)C(C)(CC(C)(C)C(C)(C)C(=O)Oc1ccc2ccccc2c1)C(=O)Oc1ccc2ccccc2c1</smiles>

1) $\mathrm{DCC} / \mathrm{CH}_{3} \mathrm{Cl}$

2) $\mathrm{H}_{2} \mathrm{~N} \frown \mathrm{Si}(\mathrm{OMe})_{3}$

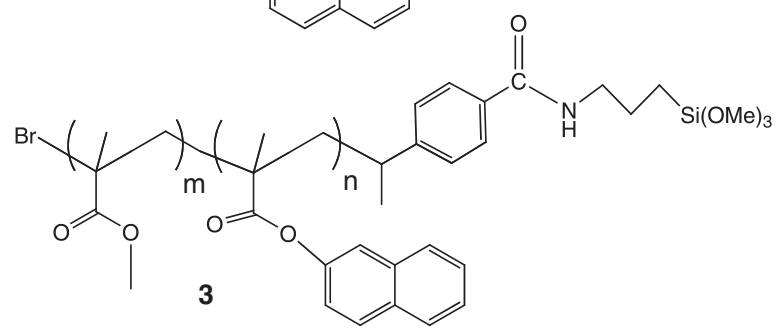

Scheme 1 Syntheses of polymeric silanes 1, 2 and $\mathbf{3}$. 
$M_{\mathrm{n}}=71800$ and $M_{\mathrm{w}} / M_{\mathrm{n}}=1.16 .{ }^{1} \mathrm{H}$ NMR $\left(\mathrm{CDCl}_{3}\right): 0.85\left(s, \mathrm{CH}_{3}\right), 1.02$ (s, $\mathrm{CH}_{3}$ ), 1.13-1.32 (broad, $\mathrm{CH}_{2}$ ), 1.71-2.14 (broad, $\mathrm{CH}_{2}$ ), 3.60 (s, $\left.\mathrm{CH}_{3}\right), 7.26$ ( $m, 3-H$ (naphthyl)), 7.40-7.54 (broad, 8- $H, 9-H$ (naphthyl)), 7.58 (broad, 10- $H$ (naphthyl)), 7.55-7.90 (broad, 4- $H, \quad 6-H, \quad 9-H$ (naphthyl)) p.p.m. Coupling the reaction of $1.1 \mathrm{~g}$ carboxyl-terminated polymer with $2.8 \mathrm{~g}$ (3-aminopropyl)trimethoxysilane in the presence of $N, N^{\prime}$ dicyclohexylcarbodiimde was performed by the same method as described in Method 2. After removing $N, N$ '-dicyclohexylurea by filtration, precipitating with methanol and drying under reduced pressure, $0.90 \mathrm{~g}$ polymer silane 3 was produced. ${ }^{1} \mathrm{H}$ NMR $\left(\mathrm{CDCl}_{3}\right): 0.84\left(s, \mathrm{CH}_{3}\right), 1.02\left(s, \mathrm{CH}_{3}\right), 1.31-1.68$ (broad, $\mathrm{CH}_{2}$ ), 1.71-2.18 (broad, $\mathrm{CH}_{2}$ ), $3.60\left(s, \mathrm{CH}_{3}\right), 7.26$ ( $m, 3-\mathrm{H}$ (naphthyl)), 7.407.54 (broad, 8- $H, 9-H$ (naphthyl)), 7.58 (broad, 10-H (naphthyl)), 7.55-7.90 (broad, 4-H, 6-H, 9-H (naphthyl)) p.p.m.

\section{Reaction of copolymer silane with colloidal silica}

A typical run went as follows. A mixture of $0.160 \mathrm{~g}$ polymer silane $\mathbf{1}$ (mole ratio MMA/NMA = 14/1), $0.40 \mathrm{ml}$ silica ethanol sol, containing $0.109 \mathrm{~g} \mathrm{SiO}_{2}$ and $20 \mathrm{ml}$ THF was stirred at room temperature for $5 \mathrm{~h}$. Next, $1.0 \mathrm{~g}$ silica gel, Wako gel C-300, was added to the suspension to remove unreacted polymer silane and its condensed products. ${ }^{11}$ After the addition of $100 \mathrm{ml}$ THF and removing the silica gel by centrifugation, the supernatant suspension containing poly(MMA-NMA)-grafted silica was available for the following experiments. After evaporation of the aliquot of the supernatant and drying under reduced pressure, the amount of grafted polymer on the silica was determined by thermal gravimetric analysis. The amounts of grafted polymer and size distribution of the poly(MMA-NMA)-grafted silica were listed in Table 1.

Inclusion of $\mathrm{C}_{60}$ into poly(MMA-NMA) chains grafted on silica A typical run went as follows. The poly(MMA-NMA)-grafted silica of $27.9 \mathrm{mg}$, composed of $11.2 \mathrm{mg} \mathrm{SiO}$, was added to the THF suspension $(3.00 \mathrm{ml})$ containing $0.068 \mathrm{mg} \mathrm{g} \mathrm{C}_{60}$, and the resulting suspension was sonicated at room temperature for 3 days to measure the particle size by dynamic light scattering. In a series of $\mathrm{C}_{60}$ inclusion tests, the amount of polymer-grafted silica was adjusted to contain $11.2 \mathrm{mg} \mathrm{SiO} 2$ in $3.00 \mathrm{ml}$ THF.

\section{Preparation of a $\mathrm{C}_{60} /$ silica PMMA hybrid film}

To THF solution $(3.00 \mathrm{ml})$ containing $24.6 \mathrm{mg}$ poly(MMA-NMA)-grafted silica included $0.027-0.25 \mathrm{mg} \mathrm{C} \mathrm{C}_{60}$, prepared from poly(MMA-NMA) silane of $M_{\mathrm{n}}=48000$ and MMA/NMA mole ratio $=7 / 1,112 \mathrm{mg}$ poly (methyl methacrylate) (PMMA) with a $M_{\mathrm{n}}=5000$ was added. The solution $(0.5 \mathrm{ml})$ was cast on a cover glass and dried under atmosphere to obtain the hybrid film.

\section{RESULTS AND DISCUSSION}

Grafting of poly(MMA-NMA) onto silica particles

Polymeric silanes 1, 2 and $\mathbf{3}$ for grafting onto silica particles were synthesized by three methods of radical polymerization to control the molecular weight. The polymeric silanes of low molecular weight, that is, 7400 and 16800 , intermediate molecular weight, that is, 33200 and 48000 , and high molecular weight, that is, 71200 and 248000 , were synthesized by Methods 1, 2 and 3, respectively, shown in Scheme 1. The grafting of poly(MMA-NMA) onto silica particles was performed by reacting the polymeric silane with silica ethanol sol in THF at room temperature for $5 \mathrm{~h}$. In Table 1, the dosed amounts of each copolymer silane, amounts of grafted polymer and size of resulting composite particles were listed. In reactions of low-molecular-weight polymeric silanes, that is, $M_{\mathrm{n}}=7400,16800$ and 33200 , with silica sol, the grafted polymer increased with an increased dosage of polymer silane, with $>90 \%$ grafted onto the silica particles. In fact, the surface hydroxyl group on colloidal silica particles $<50 \mathrm{~nm}$ is active enough to react with polymeric alkoxy silane at room temperature. ${ }^{11}$ However, the amounts of grafted polymer decreased with increased molecular weight of the copolymer silane. In the case of the reaction of polymer silane 3 with a $M_{\mathrm{n}}=248000$ with silica sol, $67 \%$ of the dosed polymer silane was bound onto the silica, most likely because of steric hindrance. The polymer grafting obviously increased the size of the poly(MMA-NMA)-grafted silica. However, distinct correlations between molecular weight of the polymer and the size were not observed.

\section{Inclusion of $\mathrm{C}_{60}$ into grafted-poly(MMA-NMA)}

After the addition of $\mathrm{C}_{60}$ to the THF suspension of poly(MMANMA)-grafted silica and sonication for $1 \mathrm{~h}$, the resulting solution became clear without the formation of $\mathrm{C}_{60}$ clusters, which was due to the inclusion of $\mathrm{C}_{60}$ into the polymer chains grafted on silica particles through the $\pi-\pi$ interaction between $\mathrm{C}_{60}$ and naphthyl group. However, it was observed that the addition of too much $\mathrm{C}_{60}$ to the suspension caused aggregation between the poly(MMA-NMA)grafted silica and $\mathrm{C}_{60}$ molecules in the suspension. As fullerenes are significantly insoluble in THF, adding them to THF forms clusters immediately, as expected. The results indicated that $\mathrm{C}_{60}$ molecules were included into the polymer chains, because the formation of clusters was never observed in the THF suspension of the polymergrafted silica after the addition of $\mathrm{C}_{60}$. In Figure 1, the dependence of the composite particle size on the amount of $\mathrm{C}_{60}$ was shown. In these cases, the grafted-polymer amounts of $1.27,2.03$ and $3.74 \mathrm{~g} / \mathrm{g}-\mathrm{SiO}_{2}$ corresponded to graft densities of $0.066,0.108$ and 0.194 chains per $\mathrm{nm}^{2}$, respectively, which were estimated based on the assumption of homogeneous polymer grafting on silica. As shown in Figure 1, the size of composite particles, including $\mathrm{C}_{60}$, was mostly independent of the amounts of grafted polymer smaller than $20 \mathrm{~nm}$ below the critical $0.2 \mathrm{mg} \mathrm{C}_{60}$ addition. However, adding more than $0.2 \mathrm{mg} \mathrm{C}_{60}$ to the suspension resulted in the formation of aggregates of the composite particles, most likely due to low polar-low polar interaction between the $\mathrm{C}_{60}$-included composite particles. Therefore, it was suggested that the inclusion of $\mathrm{C}_{60}$ into the grafted-poly(MMA-NMA) chains through the $\pi-\pi$ interaction presumably took place near the outer end parts of the grafted polymer chains on the silica.

Table 1 Preparation of poly(MMA-NMA)-grafted silica ${ }^{a}$

\begin{tabular}{|c|c|c|c|c|c|c|}
\hline \multicolumn{5}{|c|}{$\operatorname{Poly}(\mathrm{MMA}-\mathrm{NMA})-\mathrm{Si}(\mathrm{OMe})_{3}$} & \multicolumn{2}{|c|}{ Poly $(M M A-N M A) / \mathrm{SiO}_{2}$} \\
\hline \multirow[t]{2}{*}{$\begin{array}{l}\text { Prep. } \\
\text { method }\end{array}$} & \multirow[t]{2}{*}{$\mathrm{M}_{n}$} & \multirow[t]{2}{*}{$\mathrm{M}_{w} \mathrm{M}_{n}$} & \multirow[t]{2}{*}{$m / n$} & \multirow[t]{2}{*}{ Dosed amount (mg) } & $\begin{array}{c}\text { Grafted polymer } \\
\left(\mathrm{g} / \mathrm{g}-\mathrm{SiO}_{2}\right) \\
\end{array}$ & Size $(n m)$ \\
\hline & & & & & None & $9.1^{\mathrm{b}}$ \\
\hline \multirow[t]{2}{*}{1} & 7400 & 2.02 & $14 / 1$ & 133 & 1.53 & 12.3 \\
\hline & & & & 256 & 2.97 & 11.8 \\
\hline \multirow[t]{3}{*}{1} & 16800 & 1.56 & $12 / 1$ & 90 & 0.96 & 11.1 \\
\hline & & & & 170 & 1.89 & 12.1 \\
\hline & & & & 280 & 2.93 & 14.6 \\
\hline \multirow[t]{3}{*}{2} & 33200 & 1.52 & $11 / 1$ & 80 & 0.94 & 13.1 \\
\hline & & & & 120 & 1.42 & 12.4 \\
\hline & & & & 230 & 2.46 & 11.1 \\
\hline \multirow[t]{3}{*}{2} & 48000 & 2.28 & $7 / 1$ & 129 & 1.27 & 13.5 \\
\hline & & & & 221 & 2.03 & 13.0 \\
\hline & & & & 428 & 3.74 & 12.7 \\
\hline \multirow[t]{2}{*}{3} & 71800 & 1.16 & $8 / 1$ & 130 & 1.21 & 14.8 \\
\hline & & & & 220 & 2.34 & 10.1 \\
\hline 3 & 248000 & 2.19 & $9 / 1$ & 250 & 1.93 & 16.3 \\
\hline
\end{tabular}

aThe reactions were conducted using $0.40 \mathrm{ml}$ silica ethanol sol, containing $0.109 \mathrm{~g} \mathrm{SiO}_{2}$, in $20.0 \mathrm{ml}$ THF

bolydispersity index of original colloidal silica was 0.127 


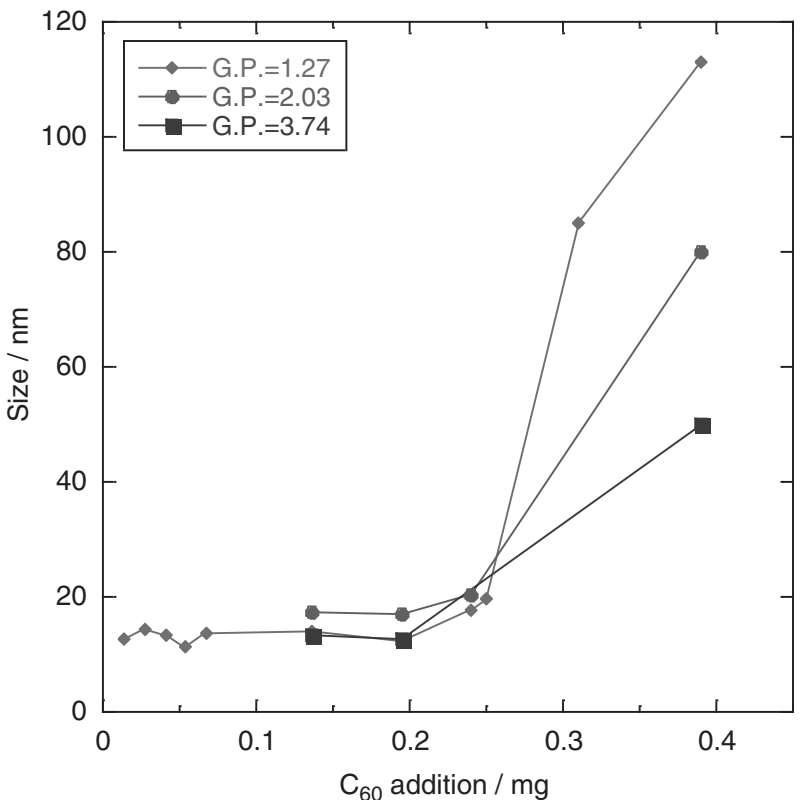

Figure 1 Changes of polymer-grafted silica size following $\mathrm{C}_{60}$ addition Grafting polymer: poly(MMA-NMA) with a $M_{n}=48000$, MMA/NMA mole ratio $=7 / 1$. G.P., grafted polymer, and the numeric values correspond to the amount of G.P. in units of $\mathrm{g} / \mathrm{g}-\mathrm{SiO}_{2}$. A full color version of this figure is available at Polymer Journal online.

The inclusion of $\mathrm{C}_{60}$ into the poly(MMA-NMA) chains grafted on silica was also affected by the molecular weight of the polymer. Figure 2 showed the relation between the amount of added $\mathrm{C}_{60}$ and the size of the composite particles, in which the amount of $\mathrm{SiO}_{2}$ in the composite particle was the same as that in Figure 1, that is, $11.2 \mathrm{mg}$. In these cases, to compare the effect of the poly(MMA-NMA) molecular weight on the $\mathrm{C}_{60}$ inclusion ability of the polymer-grafted silica particles without inducing aggregation and/or formation of $\mathrm{C}_{60}$ clusters, inclusion tests were performed by using poly(MMA-NMA)grafted silica with grafted polymers in the range of 1.2 to $1.9 \mathrm{~g} / \mathrm{g}-\mathrm{SiO}_{2}$. The inclusion of $\mathrm{C}_{60}$ into the grafted-poly(MMA-NMA) chains without aggregation between composite particles was strongly dependent on the molecular weight of the polymer. The silica composite particles grafting the polymer with an $M_{\mathrm{n}}=33200$ and 48000 afforded a higher capacity of $\mathrm{C}_{60}$ inclusion by keeping the particle size $<20 \mathrm{~nm}$, compared with composite particles with poly(MMANMA) with $M_{\mathrm{n}}=7400,16800,71200$ and 248000 . The maximum inclusion of $0.25 \mathrm{mg} \mathrm{C}_{60}$ was observed with the addition of $\mathrm{C}_{60}$ to the THF suspension of the poly(MMA-NMA)-grafted silica consisting of $11.2 \mathrm{mg} \mathrm{SiO}_{2}$ without particle aggregation, corresponding to $2.7 \mathrm{C}_{60}$ molecules per unit $12 \mathrm{~nm} \mathrm{SiO} 2$ particle (Figure 2). The reason why composite particles grafted with polymers of molecular weights of 33200 and 48000 exhibit higher $\mathrm{C}_{60}$ inclusion ability is still unclear. Most likely, in the case of the $\mathrm{C}_{60}$ inclusion using the composite particles, grafting of the low-molecular-weight poly(MMA-NMA)s with $M_{\mathrm{n}}=7400$ and 16800 was relatively high because the graft density of the grafted polymer forced the $\mathrm{C}_{60}$ molecules close together and the high affinity between $\mathrm{C}_{60}$ molecules eventually induced the aggregation between the $\mathrm{C}_{60}$-included composite particles. Otherwise, when using composite particles to graft high molecular weight poly(MMA-NMA)s, $\mathrm{M}_{\mathrm{n}}=71200$ and 248000 , the $\mathrm{C}_{60}$-included polymer chains on the silica surface have a high enough mobility to behave as a cross-linker between the $\mathrm{C}_{60}$-included composite

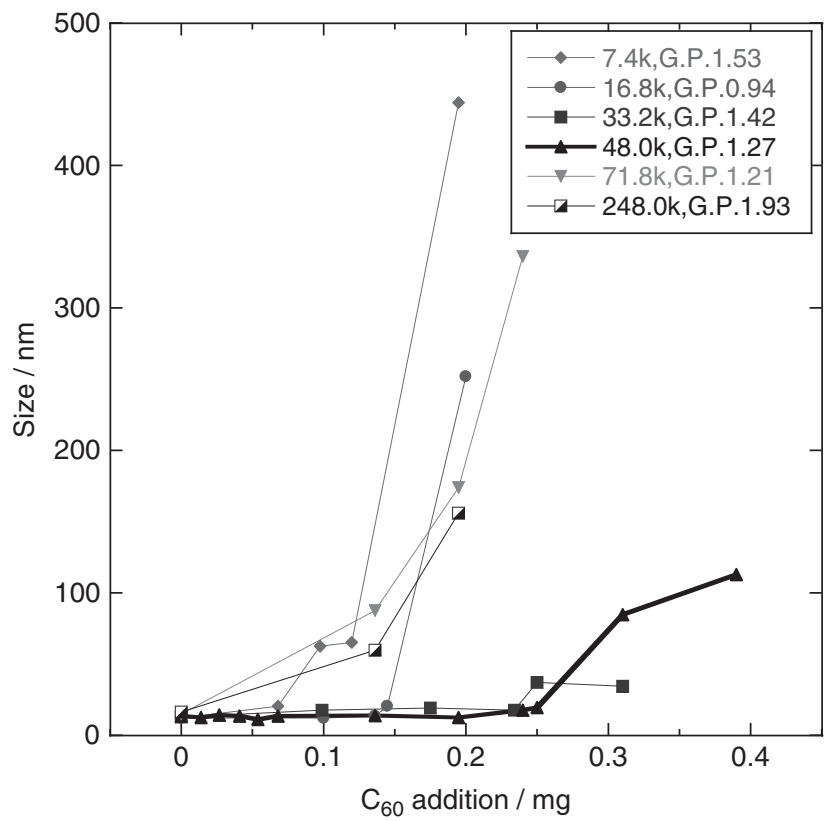

Figure 2 Effect of molecular weight of grafted poly(MMA-NMA) on silica composite size following $\mathrm{C}_{60}$ addition. G.P., grafted polymer in units of $\mathrm{g} / \mathrm{g}-\mathrm{SiO}_{2}$. A full color version of this figure is available at Polymer Journal online.

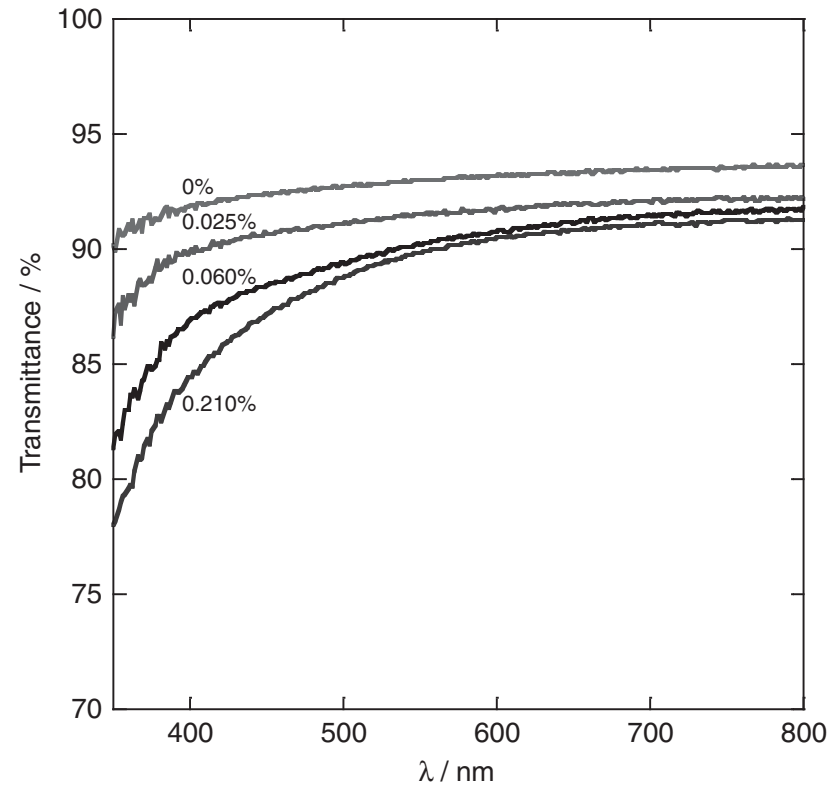

Figure 3 Transmission spectra of $\mathrm{C}_{60}$ /poly(MMA-NMA)-grafted silica/PMMA hybrid films, $50 \mu \mathrm{m}$ in thickness. Numeric values signify the $\mathrm{C}_{60}$ content of the hybrid film. Grafting polymer: poly(MMA-NMA) with a $M_{n}=48000$, MMA/NMA mole ratio $=7 / 1$. Content of $\mathrm{SiO}_{2}: 10$ wt\%. A full color version of this figure is available at Polymer Journal online.

particles through a low polar-low polar interaction; the addition of a relatively small amount of $\mathrm{C}_{60}$ induced the aggregation.

\section{$\mathrm{C}_{60}$ /silica PMMA hybrid film}

The hybrid films were prepared by casting the THF solution containing $\mathrm{C}_{60}$-included composite particles and PMMA. In 
Figure 3, the transmission spectra of the films were shown. The films, composed of $10 \mathrm{wt} \% \mathrm{SiO}_{2}$ and $\mathrm{C}_{60}$ in the range of 0.025 to $0.21 \mathrm{wt} \%$, showed transmittance $>80 \%$ in the visible light region, whereas the transmission decreased as the $\mathrm{C}_{60}$ content increased. Therefore, the included $\mathrm{C}_{60}$ molecules in the grafted poly(MMA-NMA) chains induced a small amount of aggregation between the composite particles during the casting process. Note that the transmittance decreased as the $\mathrm{C}_{60}$ content increased at a low wavelength below $500 \mathrm{~nm}$. This observation was most likely due to effective absorption by the $\mathrm{C}_{60}$ molecules. Studies related to applications of the hybrid film are now in progress.

\section{SUMMARY}

We successfully achieved inclusion of fullerene $\left(\mathrm{C}_{60}\right)$ into the graftedpoly(MMA-NMA) chains in THF without inducing the formation of $\mathrm{C}_{60}$ clusters and/or aggregation between the polymer-grafted silica particles. Polymer grafting onto silica was conducted by reacting $12 \mathrm{~nm}$ colloidal silica particles with polymeric silane, prepared by radical polymerization, in THF without particle aggregation. Molecules of $\mathrm{C}_{60}$ were effectively included into grafted polymer chains in the THF suspension of the poly(MMA-NMA)-grafted silica, prepared from polymers with molecular weights of 33200 and 48000 , without the formation of $\mathrm{C}_{60}$ clusters and without aggregation between the silica composite particles. It was observed that the maximum $\mathrm{C}_{60}$ inclusion into poly(MMA-NMA) chains grafted on $11.2 \mathrm{mg}$ silica particles was $0.25 \mathrm{mg}$, corresponding to $2.7 \mathrm{C}_{60}$ molecules per unit $\mathrm{SiO}_{2}$ particle.

1 Fukuzumi, S. \& Kojima, T. Photofunctional nanomaterials composed of multiporphirins and carbon-based p-electron acceptors. J. Matr. Chem. 18, 1427-1439 (2008).

2 Mateo-Alonso, A., Guldi, D. M., Paolussi, F. \& Prato, M. Fullerenes: multitask components in molecular machinery. Angew. Chem. Int. Ed. 46, 8120-8126 (2007).

$3 \mathrm{Li}, \mathrm{Y}$. Molecular design of photovoltaic materials of polymer solar cells: electronic energy levels and broad absorption. Acc. Chem. Res. 45, 723-733 (2012).

4 Patnaik, A. Structure and dynamics in self-organized $C_{60}$ fullerenes. J. Nanosci. Nanotechnol. 7, 1111-1150 (2007).

5 Ravi, P., Dai, S., Wang, C. \& Tam, K. C. Fullerenes containing polymers: a review on their synthesis and suparmolecular behaviour in solution. J. Nanosci. Nanotechnol. 7, 1176-1196 (2007).

6 Yoshinaga, K., Motokucho, S., Kojio, K. \& Nakai, A. Effective dispersion of fullerene with methacrylate copolymer in organic solvent and poly(methyl methacrylate). Colloid Polym. Sci. 290, 1221-1226 (2012).

7 Gieshe, M. \& Osseo-Asare, K. in Fin Particles: Synthesis, Characterization, and Mechanism of Growth (ed. Sugimoto, T.) ch. 2, 126-189 (Marcel Dekker, 2000).

8 Yoshinaga, K., Nakanishi, K., Hidaka, Y. \& Karakawa, H. Cross-linking of polymer layer on monodispersed poly(maleic anhydride-styrene)-modified colloidal silica particles, and properties of carboxyl and amino group on the surface. Composite Interfaces $\mathbf{3}$, 231-141 (1995).

9 Yoshinaga, K., Kondo, A., Higashitani, K. \& Kito, T. Immobilization of protein on monodispersed colloidal silica with poly(ethylene glycol) spacer and application of the composite to immunological agglutination test. Colloid Surf. A 77, 101-107 (1993).

10 Matyjaszewski, K. \& Xia, J. Atom transfer radical polymerization. Chem. Rev. 101, 2921-1990 (2001).

11 Yoshinaga, K., Tani, Y. \& Tanaka, Y. Surface modification of fine colloidal silica with copolymer silane-coupling agents composed of maleic anhydride. Colloids Polym. Sci. 280, 85-89 (2002). 